\title{
PENINGKATAN PENGUASAAN KOSAKATA SISWA MELALUI MEDIA GAMBAR MATA PELAJARAN BAHASA INGGRIS KELAS X.2 SMA NEGERI 1 MAGINTI TAHUN PELAJARAN 2018/2019
}

\author{
oleh: \\ PAULUS DJUANG \\ Guru SMAN 1 Maginti Kabupaten Muna Barat \\ Email:
}

\begin{abstract}
ABSTRAK
Penelitian tindakan kelas ini bertujuan untuk mendeskripsikan strategi pelaksanaan, evaluasi dan mendeskripsikan peningkatan kosa kata siswa. Penelitian tindakan kelas ini dilakukan dalam 3 siklus karena indikator penelitian baru tercapai pada siklus 3 . Di dalam setiap siklus dilakukan pengamatan dan tes kosa kata. Pada siklus pertama menggunakan media gambar, diberikan yang dicetak pada kertas, siklus ke dua menggunakan media gambar yang ditampilkan dislide dengan proyektor, pada siklus ke tiga,media gambar ditampilkan pada slide dan siswa diberikan gambar yang dicetak secara berkelompok. Masing-masing siklus di lakukan pengamatan dan tes kosa kata.Dari hasil penelitian dapat ditarik kesimpulan bahwa pembelajaran dengan menggunakan media gambar dapat meningkatkan kosa kata siswa. Pelaksanaan pembelajaran pada penelitian ini, dengan menerapkan pendekatan, yaitu konstruktivis, inkuiri, bertanya, masyrakat belajar, pemodelan, refleksi, penilain otentik.Evaluasi pembelajaran dilakukan dengan menggunakan komponen-komponen yang tepat untuk menilai kosakata siswa, yaitu (1) isi, (2) penggunaan kosa kata, (3) mekanik.Penelitian tindakan ini dilaksanakan dikelas X.2 SMA Negeri 1 Maginti ,dengan. Nilai kosa kata siswa pada siklus 1 adalah 1832, siklus 2 adalah 2000, dan siklus 3 adalah 2822 . Selanjutnya prestasi belajar siswa pada siklus 1 yang tuntas adalah 8 orang atau 22,22 $\%$, siklus 2 yang tuntas 29 orang atau $81,56 \%$ dan siklus 3 adalah 35 orang atau $97,32 \%$. Dengan demikian indicator kinerja sudah tercapai.
\end{abstract}

Kata Kunci: Media Gambar, Kosa Kata, Bahasa Inggris

PENDAHULUAN

Bahasa memiliki peran sentral dalam perkembangan intelektual, sosial, dan emosional siswa dan merupakan penunjang keberhasilan dalam mempelajari semua bidang studi. Oleh sebab itu, tujuan utama pembelajaran bahasa Inggris diarahkan untuk meningkatkan kemampuan siswa dalam berkomunikasi dengan bahasa Inggris, baik secara lisan maupun tertulis. Dalam proses pembelajaran sebagian besar siswa belum dapat mendengarkan, berbicara, membaca dan menulis dengan baik meskipun dengan kalimatkalimat sederhana, banyak siswa yang tidak menyukai pelajar bahasa Inggris siswa belum mampu berkomunikasi karena kurangnya kosa kata yang dimiliki siswa meskipun dalam bahasa atau kalimat sederhana, siswa enggan berkomunikasi karena penguasaan vocabulary yang sangat rendah. Berdasarkan nilai yang diperoleh di kelas X.2 dari ke empat keterampilan tersebut, ternyata rata-ratanya nilai rendah, yaitu 40 sedangkan ketuntasan 
belajar minimal di SMA Negeri 1 Maginti adalah 60.

Sebagian besar siswa juga tidak terlibat aktif dalam proses pembelajaran, baru sebagian kecil saja yang sudah menyenangi pembelajaran bahasa Inggris, umumnya mereka ini adalah pebelajar yang memiliki vocabulary dan kemampuan bahasa Inggris yang cukup baik sehingga mendominasi kegiatan pembelajaran. Pembelajaran selama ini masih berorientasi pada teacher centered, sehingga pelaksanaan pembelajaran masih didominasi oleh guru dan belum memanfaatkan media pembelajaran untuk memudahkan pemahaman siswa cenderung tidak tertarik dan kurang memperhatikan guru ketika proses pembelajaran berlangsung, siswa sibuk dengan temannya dan siswa lain kelihatan diam saja.

Ketika guru memberikan pertanyaan, mereka menjawab asalasalan dan sebagian lagi diam saja. Hal seperti ini dapat terjadi karena di dalam proses pembelajaran guru belum menggunakan pendekatan atau strategi yang tepat dalam proses pembelajaran dan belum menggunakan media pembelajaran. Kosakata yang dimiliki siswa sangat minim, atau mereka tidak mempunyai kosakata yang cukup sehingga mereka susah menjawab apa yang ditanyakan oleh guru. Proses evaluasi yang digunakan belum menggunakan rubrik penilaian yang tepat untuk mengukur kosakata siswa penilaian yang diberikan guru belum memperhatikan aspek-aspek yang terdapat di dalam keterampilan keempat keahlian tersebut dapat dipahami apabila dalam proses pembelajaran bahasa Inggris di SMA Negeri 1 Maginti, kemampuan siswa dalam listening, speaking, reading and writing masih sulit dipahami dan dikuasai oleh siswa.

Dalam kemampuan berkomunikasi misalnya terdapat komponen yang harus dipertimbangkan yaitu vocabulary. Di samping itu guru yang mengajarkan vocabulary perlu kesabaran yang lebih dalam membimbing siswa untuk mengeksplorasi ide-ide siswa yang beragam, karena di dalam proses pembelajaran vocabulary kemampuan untuk mengungkapkan ide merupakan hal yang paling mendasar dalam kurikulum SMA mengatakan bahwa siswa harus menguasai minimal 4000 kosa kata, sehingga mereka mampu mendengarkan, berbicara, membaca dan menulis baik lisan maupun tulisan dalam bahasa Inggris dengan baik. Sementara itu pada saat peneliti mengambil tes pendahuluan/penelitian pendahuluan, kosakata siswa hanya mencapai 1683, tidak ada satu siswa yang yang menguasai 4000 kosa kata, tentu saja hal ini sangat memperhatinkan, terlebih untuk mata pelajaran bahasa Inggris, karena bahasa Inggris salah satu mata pelajaran untuk ujian nasional. Dalam penelitian ini, peneliti hanya melakukan penelitian pada vocabulary siswa saja karena vocabulary merupakan bagian dari kemampuan mendengarkan, berbicara, membaca dan menulis, dan vocabulary merupakan hal yang bermasalah di SMA Negeri 1 Maginti, khususnya kelas X.2

Berdasarkan hal yang sudah dipaparkan di atas mendorong penulis untuk melaksanakan penelitian tindakan kelas sebagai upaya untuk meningkatkan kosakata siswa agar lebih baik atau lebih dari 2500. Peneliti membatasi jumlah kosakata siswa ini melhat karakteristik siswa dimana 
peneliti melaksanakan penelitian. Dengan gambar, kita dapat melihat sesuatu yang menarik dan berhubungan dengan kondisi yang sebenarnya.

Dengan menunjukkan gambar
guru membantu siswa r untuk
berkonsentrasi. Ini berarti bahwa
gambar dapat digunakan dalam
pembelajaran untuk memberanikan
siswa dalam belajar bahasa Inggris,
karena siswa dapat melihat objek secara
nyata. Gambar sangat penting untuk
mempelajari bahasa Inggris karena
gambar tersebut menjelaskan kata
dimana siswa belum mengerti
sebelumnya.

Pendekatan dengan menggunakan media gambar adalah suatu pendekatan dimana siswa mengaitkan materi yang diberikan dengan dunia yang nyata, media gambar diuraikan bahwa pesan yang ditampilkan melalui gambar juga dapat mendorong kemauan belajar siswa. Sedangkan dalam proses pembelajaran, siswa diharapkan mampu mengungkapkan ide-ide yang mereka miliki misalnya dalam hal menulis. Materi pelajaran yang diberikan yaitu tentang Sport, gambar-gambar diberikan kepada siswa, dan siswa menebak kata yang akan mucul dari gambar tersebut.

Berdasarkan uraian diatas, peneliti mencoba memberikan pemecahan masalah atau solusi dengan mengaplikasikan media gambar dan pegukuran kosa kata siswa di SMA Negeri 1 Maginti kelas X.2. Dengan menggunakan.media gambar dalam pembelajaran diharapkan mampu meningkatkan aktivitas belajar siswa yang pada akhirnya diharapkan dapat meningkatkan prestasi belajar siswa.

Terkait belum optimalnya hasil belajar bahasa Inggris termasuk kosa kata siswa SMA Negeri 1 Maginti, maka penulis berupaya untuk menerapkan pembelajaran dengan menggunakan media gambar sebagai salah satu alternatif pembelajaran bermakna yang bermuara pada pembelajaran yang aktif, kreatif, efektif dan menyenangkan.

\section{METODE PENELITIAN}

\section{Jenis dan Setting Penelitian}

Jenis penelitian ini adalah penelitian tindakan kelas (classroom action research) berdasarkan naturalistic kualitatif. Subyek penelitan ini adalah siswa kelas kelas X.2 SMA Negeri 1 Maginti tahun Pelajaran 2018/2019 yang bejumlah 36 Orang.

\section{Rencana Tindakan}

\section{Tahap Perencanaan}

Kegiatan ini diawali dengan orientasi, yaitu studi pendahuluan sebelum tindakan penelitian dilaksanakan. Berdasarkan hal tersebut di atas maka disusunlah rencana tindakan yang hendak dilaksanakan berupa rencana pelaksanaan pembelajaran (RPP).

\section{Tahap Pelaksanaan Tindakan}

Tahap pelaksanaan tindakan yaitu merupakan praktek pembelajaran yang nyata yang telah disusun sebelumnya. Tindakan ini ditujukan untuk memperbaiki keadaan atau proses pembelajaran.

\section{Observasi dan Evaluasi}


Peneliti melaksanakan observasi pada saat kegiatan berlangsung dengan menggunakan instrumen yang telah disiapkan guna meneliti beragam reaksi pada saat tindakan berlangsung. Observasi dilakukan dengan menggunakan observasi yang telah dipersiapkan. Apa yang diamati, siapa yang diamati, dan apa hasil yang diamati.

\section{Tahap Refleksi}

Melakukan refleksi berarti merenungkan secara intensif apa yang telah terjadi dan belum terjadi atau kekeliruan dan kekurangan dalam kegiatan pembelajaran, sehingga tampak hasil penelitian tindakan pada siklus tersebut. Dengan refleksi kita dapat mengidentifikasi serta menetapkan sasaran perbaikan baru, menyusun perencanaan baru, dan mengimplementasikan tindakan baru. Tindakan yang berhasil dilanjutkan pada kegiatan pembelajaran berikutnya. Selanjutnya tindakan yang tidak berhasil diubah dan diperbaiki.

Data prestasi belajar siswa diperoleh dari hasil tes pada akhir siklus. Berdasarkan kriteria pencapaian kosa kata, siswa dikategorikan tuntas apabila memperoleh skor 2500 kata.

\section{HASIL DAN PEMBAHASAN}

\section{Hasil Penelitian}

\section{Tindakan SIklus I}

\section{Perencanaan}

Pelaksanaan pembelajaran dengan media gambar khususnya gambargambartentang jenis-jenis olahraga. Siklus I dilaksanakan dalam dua tatap muka. Pada siklus pertama ini, peneliti memberikan materi tentang Sport, gambar- gambar diberikan kepada siswa, dan siswa menebak kata yang akan muncul dari gambar tersebut. Gambar yang dibagikan dalam bentuk berwarna dengan menggunakan kertas foto.

Sebelum melaksanakan tindakan di kelas, peneliti menyusun Rencana Pelaksanaan Pembelajaran (RPP). Sebelum membuat RPP peneliti mendiskusikan langkah- langkah yang terdapat di dalam pembelajaran media gambar tersebut, dan tindakan yang akan dilakukan di dalam pelaksanaan tindakan berikutnya. Peneliti membuat Rencana Pelaksanaan Pembelajaran (RPP) dengan menggunakan media gambar beserta contoh-contoh media gambar.RPP meliputi konstruktifis, inkuiri, bertanya, masyarakat belajar, pemodelan, refleksi dan penilaian otentik.

\section{Pelaksanaan Tindakan}

Pada langkah ini guru memberikan pertanyaan-pertanyaan seputar tema. Pada siklus pertama ini tema yang diberikan adalah favourite Sport. Langkah selanjutnya, pada kegiatan inti guru menampilkan gambar "cycling" dan memberikan pertanyaan-pertanyaan tentang "cycling tersebut, dan mengarahkan siswa untuk "menemukan kata-kata dari gambar tersebut". Sebagai contoh siswa menyebutkan kata,"play", "game over", "coach","referee, dll. Pada langkah ini peneliti menuliskan semua jawaban siswa sampai siswa menemukan semua kata. Pada tahap ini peneliti melakukan kegiatan konstruktifis dan inkuiri. Peneliti memberi kesempatan kepada siswa untuk menuliskan kata-kata yang diberikan berdasarkan contohyang 
diberikan olehguru. Selanjutnya guru membagikan kertas tes kosakata yang harus di jawab oleh siswa secara individu. Kegiatan ini berlangsung selama 60 menit.10 menit terakhir penelitian dan kolaburator mewawancarai enam orang siswa.

\section{Observasi}

Berdasarkan lembar observasi siswa, siswa mulai terlibat aktif dibandingkan dengan proses pembelajaran sebelum menggunakan media gambar. Untuk kegiatan bertanya, sebagian siswa sudah memberikan pertanyaan-pertanyaan kepada guru, namun pada saat guru memberikan pertanyaan, hanya siswa tertentu saja yang mau mengangkat tangan untuk menjawab. Belum seluruh siswa berjalan aktif, hal ini disebabkan karena dalam beberapa kegiatan guru belum memberikan kesempatan kepada siswa untuk terlibat dalam proses pembelajaran. Secara keseluruhan proses pembelajaran belumberjalan dengan baik.

Tabel 1. Aktivitas belajar Siswa Siklus 1

\begin{tabular}{llllll}
\hline \multirow{2}{*}{ No } & $\begin{array}{l}\text { Aspek yang } \\
\text { Diminati }\end{array}$ & \multicolumn{2}{c}{ Aktif } & \multicolumn{2}{c}{$\begin{array}{c}\text { Tidak } \\
\text { Aktif }\end{array}$} \\
\cline { 2 - 6 } 1 & F & \% & F & \% \\
\hline & $\begin{array}{l}\text { Megemukakan } \\
\text { pendapat } \\
\text { didepan kelas }\end{array}$ & 23 & 3.89 & 13 & 36.11 \\
\hline & $\begin{array}{l}\text { Memberikan } \\
\text { jawaban atas } \\
\text { pertanyaan } \\
\text { guru }\end{array}$ & 17 & 47.22 & 19 & 52.78 \\
\hline 3 & $\begin{array}{l}\text { Mengajukan } \\
\text { pertanyaan } \\
\text { pada guru }\end{array}$ & 16 & 44.44 & 20 & 55.56 \\
\hline 4 & $\begin{array}{l}\text { Berlatih } \\
\text { menggunakan } \\
\text { bahasa inggris }\end{array}$ & 14 & 38.89 & 2 & 61.11 \\
\hline
\end{tabular}

\begin{tabular}{llllll}
5 & $\begin{array}{l}\text { Melafalkan } \\
\text { kata dalam } \\
\text { bahasa inggris }\end{array}$ & 24 & 66.67 & 2 & 33.33 \\
\hline 6 & $\begin{array}{l}\text { Berdialog } \\
\text { dengan sesama } \\
\text { taman }\end{array}$ & 18 & 50 & 18 & 50 \\
\hline 7 & $\begin{array}{l}\text { Menggunakan } \\
\text { kata } \\
\text { (vocabulary) } \\
\text { secara benar }\end{array}$ & 22 & 61.11 & 14 & 38.89 \\
\hline
\end{tabular}

\section{Refleksi}

Kegiatan observasi di kelas X.2 dapat di deskripsikan sebagai berikut, observasi dilakukan bersamaan dengan pelaksanaan tindakan untuk mengukur ketercapain indicator. Hasil observasi kelas X.2 pada siklus 1, Rencana pelaksanaan pembelajaran yang dibuat guru belum dapat meningkatkan proses pembelajaran dengan baik. Namun menerapkan pendekatan dengan menggunakan media gambar lebih baik terhadap proses pembelajaran. Rencana pembelajaran yang dibuat guru belum dapat membuat siswa aktif dalam proses pembelajaran.

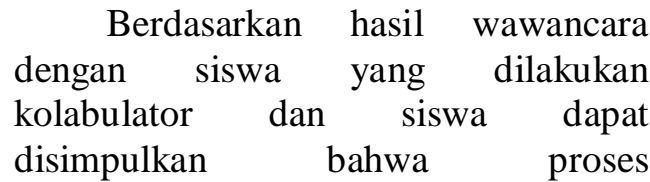
pembelajaran masih membingungkan. Di dalam kegiatan pembelajaran mereka masih belum banyak terlibat dalam proses pembelajaran. Guru masih terlalu cepat memberikan materi. Hasil wawancara yang dilakukan dengan siswa, proses pembelajaran media gambar untuk meningkatkan kosakata siswa belum berjalan dengan baik.

Tabel 2. Pencapaian Kosakata Siswa
Berdasarkan Frekwensi
Absolut dan Frekwensi
Presentase kelas X.2 pada
siklus I




\begin{tabular}{cccc}
\hline No. & $\begin{array}{c}\text { Pencapaian } \\
\text { kosakata }\end{array}$ & $\begin{array}{c}\text { Frekuensi } \\
\text { Absolute }\end{array}$ & $\begin{array}{c}\text { Frekuensi } \\
\text { presentase }\end{array}$ \\
\hline 1 & $0-500$ & 0 & 0 \\
\hline 2 & $501-1001$ & 0 & 0 \\
\hline 3 & $1001-1501$ & 4 & $11.11 \%$ \\
\hline 4 & $1501-2001$ & 24 & $66.67 \%$ \\
\hline 5 & $2001-2501$ & 8 & $22.22 \%$ \\
\hline 6 & $2501-3001$ & 0 & 0 \\
\hline 7 & $3001-3501$ & 0 & 0 \\
\hline
\end{tabular}

\section{Tindakan Siklus II}

\section{Perencanaan}

Sebelum melaksanakan tindakan di kelas pada siklus ke 2, peneliti dan kolabulator menyusun perencanaan tindakan (RPP), yang disusun berdasarkan langkah-langkah dan hasil refleksi pada siklus pertama. Pada pembuatan RPP pada siklus kedua menekankan pada kegiatan inkuiri. Pada langkah inkuiri pembelajaran dirancang dengan memberikan beberapa gambar, diharapkan dengan pemberian beberapa gambar siswa dapat terpancing untuk mengungkapkan pendapatnya dan akhirnya dapat.melakukan proses inkuri.

\section{Pembuatan RPP pada siklus} kedua, nampaknya guru mulai memahami langkah-langkah kegiatan yang akan dilakukan. Sebelum melaksanakan siklus 2 guru dan kolaburator melakukan diskusi. Hal ini dilakukan agar anggota tim mempunyai pemahaman yang sama mengenai media gambar dalam pembelajaran. Seperti pada siklus pertama, pada siklus kedua ini, tim peneliti mempersiapkan instrument penelitian yaitu lembar, pengamatan pembelajaran media gambar, lembar pengamatan siswa, panduan wawancara, dan lembar soal kegiatan siswa.

\section{Pelaksanaan Tindakan}

Proses pembelajaran diawali dengan memberi salam kepada siswa "good morning, my students" yang dijawab spontan oleh siswa "good morning, sir" How are you? Lalu siswa menjawab "fine, thanks". Pada tatap muka pertama siklus kedua, pada kegiatan pendahuluan guru menjelaskan tentang tema yang akan disiswai. Pada langkah ini guru memberikan pertanyaanpertanyaan seputar tema.

Tema siklus kedua adalah Domestic Tourism. Pada langkah ini guru mencoba mengkonstruksi pengetahuan siswa dan melaksanakan langkah bertanya melalui kegiatan pendahuluan. Pada kegiatan inti guru menanyangkan beberapa gambar, dan selanjutnya guru meminta siswa untuk memikirkan kata-kata yang muncul dari gambar-gambar tersebut.

Langkah selanjutnya peneliti membuka kesempatan kepada siswa untuk bertanya tentang gambar yang diberikan. Pada langkah ini guru melaksanakan kegiatan bertanya. Peneliti menjawab pertanyaan siswa dan menjelaskan materi sedikit demi sedkit. Berikutnya memberikan kesempatan kepada siswa untuk mengamati dan melihat gambar tersebut. Langkah selanjutnya siswa dimint untuk mengungkapkan pendapatnya tentang gambar-gambar tersebut.

Pada kegiatan penutup guru memberikan pertanyaan-pertanyaan tentang materi yang diberikan, dan memberikan kesempatan kepada siswa untuk bertanya tentang materi yang belum dipahami. Kegiatan ini dilakukan untuk melaksanakan refleksi. Langkah selanjutnya guru menyimpulkan materi. 


\section{Pengamatan}

Berdasarkan lembar observasi siswa, siswa lebih aktif jika dibandingkan dengan siklus pertama. Pada siklus pertama siswa tidak mengeluarkan pendapatnya, pada siklus kedua dilaksanakan dengan baik oleh siswa. Untuk kegiatan bertanya dan menjawab pertanyaan yang diberikan oleh guru sebagian besar siswa sudah terlibat. Guru dan kolaburator sudah semakin baik dalam melaksanakan penilain karena semakin memahami rubrik yang disediakan.

Tabel 3. Aktivitas Belajar Siswa Siklus

\begin{tabular}{|c|c|c|c|c|c|}
\hline \multirow{3}{*}{ No } & \multirow{3}{*}{$\begin{array}{c}\text { Aspek yang } \\
\text { Diminati }\end{array}$} & \multicolumn{4}{|c|}{ Frek aktivitas siswa } \\
\hline & & \multicolumn{2}{|c|}{ Aktif } & \multicolumn{2}{|c|}{$\begin{array}{l}\text { Tidak } \\
\text { Aktif }\end{array}$} \\
\hline & & $\mathrm{F}$ & $\%$ & $\mathrm{f}$ & $\%$ \\
\hline 1 & $\begin{array}{l}\text { Mengemukakan } \\
\text { pendapat } \\
\text { didepan kelas }\end{array}$ & 24 & 66.67 & 12 & 33.33 \\
\hline 2 & $\begin{array}{l}\text { Memberikan } \\
\text { jawaban atas } \\
\text { pertanyaan } \\
\text { guru }\end{array}$ & 18 & 50 & 18 & 50 \\
\hline 3 & $\begin{array}{l}\text { Mengajukan } \\
\text { pertanyaan } \\
\text { pada guru }\end{array}$ & 18 & 50 & 18 & 50 \\
\hline 4 & $\begin{array}{l}\text { Berlatih } \\
\text { menggunakan } \\
\text { bahasa inggris }\end{array}$ & 18 & 50 & 18 & 50 \\
\hline 5 & $\begin{array}{l}\text { Melafalkan } \\
\text { kata dalam } \\
\text { bahasa inggris }\end{array}$ & 26 & 72.22 & 10 & 27.78 \\
\hline 6 & $\begin{array}{l}\text { Berdialog } \\
\text { dengan sesama } \\
\text { teman }\end{array}$ & 19 & 52.78 & 17 & 47.22 \\
\hline 7 & $\begin{array}{l}\text { Menggunakan } \\
\text { kata } \\
\text { (vocabulary) } \\
\text { secara benar }\end{array}$ & 24 & 66.67 & 12 & 33.33 \\
\hline
\end{tabular}

\section{Refleksi}

Pelaksanaan evaluasi yang dilakukan sudah mengalami kemajuan karena peneliti sudah lebih baik didalam menggunakan rubric penilaian memperhatikan komponen didalam kosakata.

Berdasarkan data hasil yang dicapai oleh siswa dan proses pembelajaran media gambar, pada siklus 2 ini masih belum berhasil dengan baik. Sehingga perlu diadakan siklus 3 untuk memperbaiki proses pembelajaran dan hasil kosakata siswa. Proses pembelajaran yang dilakukan pada siklus 2 mengalami peningkatan, hanya pada kegiatan diskusi siswa belum maksimal sehingga pada siklus 3 guru harus lebih jelas lagi menjelaskan kegiatan atau langkah-langkah yang harus dilakukan didalam kegiatan diskusi. Guru tidak terlalu cepat dalam menjelaskan materi sehingga beberapa siswa merasa sulit untuk memahami.

Tabel 4. Pencapaian kosakata siswa berdasarkan frekwensi absolute dan frekwensi prosentase kelas X2 pada siklus II

\begin{tabular}{cccc}
\hline No & $\begin{array}{c}\text { Pencapaian } \\
\text { Kosa kata }\end{array}$ & $\begin{array}{c}\text { Frekuensi } \\
\text { Absolute }\end{array}$ & $\begin{array}{c}\text { Frekuensi } \\
\text { presentase(\%) }\end{array}$ \\
\hline 1 & $0-500$ & 0 & 0 \\
\hline 2 & $501-1001$ & 0 & 0 \\
\hline 3 & $1001-1501$ & 0 & 0 \\
\hline 4 & $1501-2001$ & 7 & $19.44 \%$ \\
\hline 5 & $2001-2501$ & 20 & $55.56 \%$ \\
\hline 6 & $2501-3001$ & 9 & $25.00 \%$ \\
\hline 7 & $3001-3501$ & 0 & 0 \\
\hline
\end{tabular}

Tindakan Siklus III

\section{Perencanaan}

Pada siklus tiga RPP dirancang untuk meningkatkan kegiatan diskusi. Pada langkah ini guru akan mendatangi kelompok-kelompok memperlihatkan gambar dan 
menunjukkan kata-kata dari gambar tersebut.

Disamping itu guru akan melakukan tanya jawab dalam kelompok diskusi tersebut sehingga siswa benar-benar memahami kegiatan diskusi. Selain membuat RPP, peneliti dan kolabulator mendiskusikan tindakan-tindakan yang akan dilakukan pada siklus ketiga. Hal ini dilakukan agar peneliti dan kolabulator mempunyai persepsi yang sama dalam proses pembelajaran kosakata dengan menggunakan media gambar. Peneliti dan kolabulator mempersiapkan instrumen untuk pelaksanaan siklus ketiga. Instrument tersebut adalah lembar pengamatan pembelajaran media gambar, pedoman wawancara, dan lembar soal untuk kegiatan kosakata.

\section{Pelaksanaan tindakan}

Pada kegiatan pendahuluan guru memberikan pertanyaan-pertanyaan seputar tema untuk brain storming dengan kegiatan ini diharapkan siswa dapat lebih terarah memahami tema yang akan disiswai. Pada langkah ini guru melaksanakan kegiatan konstruktifis dan bertanya. Tema pada siklus ketiga ini adalah Ancient History.

Pada kegiatan inti pada silkus 3 guru memberikan 2 buah gambar. Dengan pemberian 2 buah gambar, siswa terpancing untuk bertanya tentang kedua gambar tersebut. Guru menjawab pertanyaan-pertanyaan siswa dan menjelaskan materi sedikit demi sedikit. Pada langkah selanjutnya guru memberikan kesempatan kepada siswa untuk mengamati gambar tersebut. Setelah siswa mengamati gambar tersebut, siswa diminta untuk mengungkapkan pendapatnya tentang gambar tersebut. Pada langkah berikutnya siswa menuliskan kata-kata yang muncul dari gambar yang ditanyangkan oleh guru ke dalam buku catatan siswa.

Selanjutnya guru membagikan soal tes kosakata dan siswa menjawab secara individu. Pada 10 menit terakhir, peneliti dan kolabulator mewawancarai enam orang siswa untuk mewakili teman-temanya. Tujuan dari wawancara ini untuk mengetahui tanggapan siswa terhadap proses pembelajaran kosakata pada siklus ketiga.

\section{Observasi}

Proses pembelajaran kosakata dengan menggunakan media gambar mengalami perbaikan jika dibandingkan dengan siklus pertama dan kedua. Pada pelaksanaan siklus kedua, guru mulai mengalami perbaiakn dalam melaksanakan langkah- langkah pendekatan media gambar Inkuiri yang pada siklus sebelumnya masih belum nampak, pada siklus ini siswa sudah mulai terpancing dengan kegiatan yang diberikan oleh guru. Siswa sudah mau untuk bertanya, mengungkapkan idenya.

Pada siklus 3 guru melakukan penjelasan yang sangat mendetail untuk setiap langkah diskusi sehingga siswa tidak merasa bingung dan makin jelas dalam melaksanakan diskusi yang dilakukannya, sehingga pelaksanaan diskusi berjalan dengan baik. Dampak dari kegiatan diskusi yang berjalan dengan baik, suasana kelas makin hidup, semua siswa terlihat senang dengan kegiatan diskusi yang mereka lakukan. Guru memantau kegiatan diskusi dengan cara mendatangi masing-masing kelompok. Pada siklus ketiga ini seluruh siswa mencapai kosakata 664, 539, 493, 417. Dan rata- 
rata kelas mencapai 2822 .

Tabel 5. Aktivitas belajar Siswa Siklus III

\begin{tabular}{|c|c|c|c|c|c|}
\hline \multirow{3}{*}{ No } & \multirow{3}{*}{$\begin{array}{l}\text { Aspek yang } \\
\text { Diminati }\end{array}$} & \multicolumn{4}{|c|}{ Frek aktivitas siswa } \\
\hline & & \multicolumn{2}{|c|}{ Aktif } & \multicolumn{2}{|c|}{$\begin{array}{l}\text { Tidak } \\
\text { Aktif }\end{array}$} \\
\hline & & $\mathrm{F}$ & $\%$ & $\mathrm{f}$ & $\%$ \\
\hline 1 & $\begin{array}{l}\text { Mengemukakan } \\
\text { pendapat } \\
\text { didepan kelas }\end{array}$ & 26 & 72.22 & 10 & 27.78 \\
\hline 2 & $\begin{array}{l}\text { Memberikan } \\
\text { jawaban atas } \\
\text { pertanyaan }\end{array}$ & 20 & 55.56 & 16 & 44.44 \\
\hline 3 & $\begin{array}{l}\text { Mengajukan } \\
\text { pertanyaan } \\
\text { pada guru }\end{array}$ & 20 & 55.56 & 16 & 44.44 \\
\hline 4 & $\begin{array}{l}\text { Berlatih } \\
\text { menggunakan } \\
\text { bahasa inggris }\end{array}$ & 19 & 52.78 & 17 & 47.22 \\
\hline 5 & $\begin{array}{l}\text { Melafalkan } \\
\text { kata dalam } \\
\text { bahasa inggris }\end{array}$ & 29 & 80.56 & 7 & 19.44 \\
\hline 6 & $\begin{array}{l}\text { Berdialog } \\
\text { dengan sesama }\end{array}$ & 27 & 75 & 9 & 25 \\
\hline 7 & $\begin{array}{l}\text { Menggunakan } \\
\text { kata } \\
\text { (vocabulary) } \\
\text { secara benar }\end{array}$ & 28 & 77.78 & 8 & 22.22 \\
\hline
\end{tabular}

Pada siklus III pembelajaran media gambar telah dilaksanakan dengan baik oleh guru, sehingga indicator yang diharapkan dapat terpenuhi pada siklus ketiga ini. Guru telah melakukan konstruktivisme, bertanya, melakukan pemodelan, melaksanakan inkuiri, melakukan refleksi dan melaksanakan penilaian otentik dengan baik. Pelaksanaan evaluasi telah dilakukan dengan baik oleh guru.

Vocabulary siswa dapat tercapai sesuai dengan indicator yang diharapkan. Pada siklus ketiga seluruh siswa dapat mencapai kosakata 687, 668, 731, 737 dan rata- rata kelas 2822 . Berdasarkan lembar pengamatan tentang kegiatan siswa pada siklus ketiga, sebagian besar siswa sudah aktif dalam mengikuti proses pembelajaran sesuai dengan harapan yang diinginkan dalam penelitian ini.

Selanjutnya peneliti membuat sebuah tabel yang berisi pencapaian kosa kata pada siklus III kelas X2 dengan jumlah siswa 36 adalah sebagai berikut:

Tabel 6. Pencapaian Kosa Kata pada Siklus III

\begin{tabular}{cccc}
\hline No & $\begin{array}{c}\text { Pencapaian } \\
\text { kosakata }\end{array}$ & $\begin{array}{c}\text { Frekuensi } \\
\text { Absolute }\end{array}$ & $\begin{array}{c}\text { Frekuensi } \\
\text { presentase } \\
(\%)\end{array}$ \\
\hline 1 & $0-500$ & 0 & 0 \\
\hline 2 & $501-1001$ & 0 & 0 \\
\hline 3 & $1001-1501$ & 1 & $2.78 \%$ \\
\hline 4 & $1501-2001$ & 8 & $22.22 \%$ \\
\hline 5 & $2001-2501$ & 15 & $41.67 \%$ \\
\hline 6 & $2501-3001$ & 11 & $30.55 \%$ \\
\hline 7 & $3001-3501$ & 1 & $2.78 \%$ \\
\hline
\end{tabular}

\section{Pembahasan}

Peneliti menyusun RPP dengan menggunakan pendekatan yang menggunakan media gambar. Di dalam RPP berisi tentang tujuan pembelajaran, materi siswa, langkah-langkah pembelajaran, dan evaluasi. Tujuan pembelajaran sangat penting diketahui siswa karena dengan penjelasan tujuan yang akan dicapai siswa, maka kita akan mengetahui arah proses pembelajaran Materi pembelajaran kosakata.

Dengan menggunakan beragam media gambar. Strategi pembelajaran atau langkah-langkah ppembelajaran yang disusun dalam RPP menerapkan tujuh komponen pendekatan yaitu: konstruktivisme, inkuiri, bertanya, 
masyarakat belajar, pemodelan, refleksi, danpenilaian otentik.

Rencana Pelaksanaan

Pembelajaran disusun sebagai pedoman dalam pelaksanaan pembelajaran agar arah dan tujuan dapat tercapai. Penggunaan RPP yang disusun dan direvisi dengan menerapkan media gambar mampu meningkatkan proses pembelajaran yang berdampak pada peningkatan jumlah kosakata siswa pada siswa kelas X.2 SMA Negeri 1 Maginti.

Di dalam perencanaan tindakan, peneliti mempersiapkan instrument penelitian, yaitu: (1) lembar observas isiswa, (2) lembar tes kosakata, (3) pedoman wawancara. Tes yang digunakan pada penelitian ini adalah menjodohkan dimana siswa memilih salah satu jawaban berdasarkan arti dari kata tersebut Pedoaman wawancara disusun untuk mengetahui tanggapan siswa terhadap proses pembelajaran. Tanggapan siswa sangat penting untuk diperhatikan dalam rangka menyusun tindakan/penyusunan RPP untuk siklus berikutnya. Rata-rata kosakata siswa dapat dilihat dari tabel berikut ini:

Tabel 7. Nilai Kosa Kata Siswa

\begin{tabular}{cc} 
Siklus & $\begin{array}{c}\text { Rata-rata Kosakata siswa } \\
\text { kelas X.2 }\end{array}$ \\
\hline 1 & 1832 \\
\hline 2 & 2000 \\
\hline 3 & 2822 \\
\hline
\end{tabular}

Pendekatan yang digunakan didalam proses pembelajaran media gambar mampu meningkatkan kosakata siswa. Penilaian tersebut mencapai indikator pada siklus. Pendekatan media gambar yang digunakan di dalam proses pembelajaran sangat membantu siswa untuk mengungkapakan ide-ide mereka.

Dengan menggunakan beragam gambar dan contoh-contoh pemodelan yang diberikan dengan membuat siswa berhadapan langsung dengan lingkungan yang nyata, siswa mengaitkan materi pembelajaran dengan dunia nyata mereka hingga siswa dapat menuangkan ide-ide yang mereka dengan lancar sehingga berdampak pada kosa kata mereka.

\section{KESIMPULAN}

Hasil penelitian dapat ditarik kesimpulan bahwa pembelajaran dengan menggunakan media gambar dapat meningkatkan kosa kata siswa. Pelaksanaan pembelajaran pada penelitian ini, dengan menerapkan pendekatan, yaitu konstruktivis, inkuiri, bertanya, masyrakat belajar, pemodelan, refleksi, penilain otentik. Evaluasi pembelajaran dilakukan dengan menggunakan komponen-komponen yang tepat untuk menilai kosakata siswa, yaitu (1) isi, ( 2) penggunaan kosa kata, (3) mekanik.

Penelitian tindakan ini dilaksanakan dikelas X.2 SMA Negeri 1 Maginti, dengan. Nilai kosa kata siswa pada siklus 1 adalah 1832, siklus 2 adalah 2000, dan siklus 3 adalah 2822. Selanjutnya prestasi belajar siswa pada siklus 1 yang tuntas adalah 8 orang atau $22,22 \%$, siklus 2 yang tuntas 29 orang atau 81,56\% dan siklus 3 adalah 35 orang atau 97,32\% Dengan demikian indicator kinerja sudah tercapai. 


\section{DAFTAR PUSTAKA}

\section{AECT. 1977. The Definitionof Eduational Technology, Association for Education Communication and Tehnology.}

Ag.Setyadi Bambang. 2006. Teaching English As a Foreign Language. Yogyakarta. GrahaIlmu

Anggowo dan Kosasih. 2007. Optimalisasi Media Pembelajaran. Grafindo. Jakarata.

Annurahman. 2009. Belajar dan Pembelajaran. Alfabeta. Bandung

Brunner, J. 1990. ACTS of Meaning. Cambridge. Harvard University Press.

Carrand Kemmis. 1986. Action Research Principlesand Practice Lecturein Education. University of Bath.

Conny Semiawan, dkk. 1990. Pendekatan Keterampilan Proses. Jakarta: Gramedia.

Departemen Pendidikan Nasional. 2003. Pedoman Pengembangan Silabus. Jakarta.

Harmer, Jeremy. 1993. The practice of English Language Teaching. London. Longman Group.

Harrow, A. J. 1972. A taxomyof the psychomotor domain: A guided for developing behavioral objective. New York: David Mc Key Company.

I.S.P. Nation. 1990. Teaching and
Learning Vocabulary, Heinle and Heinle Publishers, Boston.

Ongkosaputro. 2009. English Vocabular. Jakarta: PT Wahyu Media

J.B.Heaton. 1998. Writing English Lanuage Tests. England: Longman Group UK Limited

Jean Mc Niff. 1995. Action Research Principles and Practice. NewYork.: NY.

LexyJ. Moleong. 2006. Metodologi Penelitian Kualitatif. Bandung: Remaja Rosda karya.

Mardapi, Dj. Dan Ghofur,A. 2004. Pedoman Umum Pengembangan Penelitian kurikulum Berbasis Kompetensi SMA. Jakarta: Direktorat Pendidikan Menengah Umum.

Mc.Taggart, R dan Kemmis,S. 1990. The Action Research Planner. Melbourne: Deakin University.

Nana Sudjana. 1995. Dasar-dasar Proses Belajar Mangajar. Bandung: Sinar Baru Algensindo.

Nasib Sulhan. 2006. Pembangunan Karakter Pada Anak Manajemen Pembelajarn Guru Menuju Sekolah Efektif. Surabaya: SIC.

Peraturan Pemerintah. 2005. tentang Standar Nasional Pendidikan. Jakarta: Fokus Media.

Scott Thornbury. 2005. How to Teach Vocabulary. England: Pearson Education Limited.

Slameto. 2003. Belajar dan Faktor- 
Faktor yang Mempengaruhi.

Jakarta: Rineka Cipta.

Sugiyono. 2003. Metode Penelitian Kualitatif dan $R$ \& D. Bandung: Alfabeta.

Sunyono. 2008. Penelitian Tindakan Kelas (PTK). Lampung.

Suyanto, 1997. Penelitian Tindakan: Guru Sebagai Peneliti. Bahan Penelitian PTK Guru SLTP dan SMU. Malang. Lembaga Penelitian. IKIP Malang.

Syaiful Bahri Djamarah dan Aswan Zain. 2006. Strategi Belajar Mengajar. Jakarta: Rineka Cipta.

W. Gulo. 2002. Strategi Belajar Mengajar. Jakarta: Grasindo 